\title{
Pengaruh Musik Latar Terhadap Kenyamanan Kerja Karyawan Bank BCA
}

\author{
M. Alfiah Akbar \\ Prodi Musik Fakultas Seni Pertunjukan Institut Seni Indonesia Yogyakarta
}

\begin{abstract}
Fostering and maintaining a comfortable work environment is an important target in relation to the management and development of human resources in the company. One effort to create employee work comfort is to listen to music, because music can provide a new atmosphere for the work environment. The purpose of this study is to test the hypothesis "There is an increase in work comfort for BCA employees when playing background music" and identify the level of work comfort of employees after listening to music and identify the type of background music that can support the comfort atmosphere of BCA employee work. The method used in this research is quantitative with a quasi-experimental approach. The quasi-experimental design used is the Pre-test Post-test Control Group Design. The research subjects were 30 employees of the Bank BCA Finance Division, 15 control groups (KK) and 15 experimental groups (KE). Collecting data in this study using a work comfort questionnaire, the results of calculations using the t-test showed a tvalue of 0.113 ( $p>0.05$ ), then Ho was accepted and Ha was rejected. This means that there is no significant increase in work comfort in the control group. Next test the pretest and posttest values in the experimental group. The results of calculations using the $t$-test showed a t value of $0.01(p<0.05)$, then Ha was accepted and Ho was rejected. Based on the results of the analysis, it can be concluded that there is a significant increase in work comfort in the experimental group.
\end{abstract}

Keywords: Background music, work comfort, moods, emotions.

\begin{abstract}
Abstrak
Pembinaan dan pemeliharaan lingkungan kerja yang nyaman merupakan sasaran yang penting dalam kaitannya dengan pengelolaan dan pengembangan sumber daya manusia dalam perusahaan. Salah satu upaya untuk menciptakan kenyamanan kerja karyawan adalah dengan mendengarkan musik, karena musik dapat memberikan suasana baru bagi lingkungan kerja. Tujuan dari penelitian ini adalah untuk menguji hipotesis “Ada peningkatan kenyamanan kerja pada karyawan BCA saat diperdengarkan musik latar" dan mengidentifikasi tingkat kenyamanan kerja karyawan setelah mendengarkan musik serta mengidentifikasi jenis musik latar yang dapat mendukung suasana kenyamanan kerja karyawan BCA. Metode yang digunakan dalam penelitian ini adalah kuantitatif dengan pendekatan kuasi eksperimen. Adapun desain kuasi ekperimen yang digunakan adalah Pretest Post-test Control Group Desain. Subjek penelitian adalah 30 orang karyawan Divisi Keuangan Bank BCA, 15 orang kelompok kontrol (KK) dan 15 orang kelompok eksperimen (KE). Pengumpulan data dalam penelitian ini menggunakan kuesioner kenyamanan kerja, Hasil perhitungan menggunakan t-test menunjukkan nilai $\mathrm{t}$ sebesar 0,113 ( $\mathrm{p}>0,05$ ), maka Ho diterima dan Ha ditolak. Hal tersebut berarti bahwa tidak terdapat peningkatan kenyamanan kerja yang signifikan pada kelompok kontrol. Selanjutnya melakukan uji nilai pretest dan posttest pada kelompok eksperimen. Hasil perhitungan menggunakan t-test menunjukkan nilai t sebesar $0,01 \quad(p<0,05)$, maka Ha diterima dan Ho ditolak. Berdasarkan hasil analisis tersebut, dapat disimpulkan bahwa terdapat peningkatan kenyamanan kerja yang signifikan pada kelompok eksperimen.
\end{abstract}

Kata kunci: Musik latar, kenyamanan kerja, suasana hati, emosi

\section{Pengantar}

Semangat kerja dan produktivitas karyawan dalam perusahaan cenderung berubah-ubah dan mengalami pasang surut sehingga perilaku karyawan tidak selalu stabil. Salah satu akibat dari menurunnya produktivitas 
kerja yang perlu mendapatkan perhatian adalah kurang nyamannya kondisi karyawan di tempat kerja (Idrus, 2006). Oleh karena itu pembinaan dan pemeliharaan lingkungan kerja yang nyaman merupakan sasaran yang penting dalam kaitannya dengan pengelolaan dan pengembangan sumber daya manusia dalam perusahaan.

Salah satu upaya untuk menciptakan kenyamanan kerja karyawan adalah dengan mendengarkan musik, karena musik dapat memberikan suasana baru bagi lingkungan kerja. Bekerja dan mendengarkan musik seolah dua aktifitas yang bertolak belakang, bekerja identik dengan aktifitas yang membutuhkan konsentrasi, sementara mendengarkan musik seringkali dikaitkan dengan kegiatan mencari hiburan atau kesenangan. Namun hal tersebut tidak menjadikan keduanya tidak bisa dilakukan secara bersamaan.

Meskipun ada semakin banyak penelitian yang meneliti tentang praktek mendengarkan musik dalam kehidupan sehari-hari, tetapi sedikit yang diketahui tentang penggunaan musik di lingkungan kantor khususnya di Indonesia. Oleh sebab itu, tujuan dari penelitian ini adalah untuk menguji hipotesis "Ada peningkatan kenyamanan kerja pada karyawan BCA saat diperdengarkan musik latar" dan mengidentifikasi tingkat kenyamanan kerja karyawan setelah mendengarkan musik serta mengidentifikasi jenis musik latar yang dapat mendukung suasana kenyamanan kerja karyawan BCA.

\section{Metode}

Penelitian ini menggunakan pendekatan kuasi eksperimen, adapun desain kuasi ekperimen yang digunakan adalah Pre-test Post-test Control Group Desain. Sampel terdiri dari 30 orang karyawan biro keuangan bank BCA di Jakarta Pusat. 15 orang kelompok kontrol dan 15 orang kelompok eksperimen.
Penelitian ini menggunakan dua alat pengumpulan data, pertama observasi yang berguna untuk menggali data kualitatif mengenai kondisi pekerjaan yang dilakukan oleh karyawan, situasi lingkungan kerja, dan dinamika perilaku karyawan selama mengikuti proses eksperimen. Kedua, kuesioner Positive and Negative Affect Schedule (PANAS) (Watson dan Clark, 1988) yang terdiri dari 10 indikator positif dan 10 indikator negatif yang telah dimodifikasi menjadi 16 indikator. Kemudian subjek diminta untuk menunjukkan sampai sejauh mana pernyataan menjelaskan apa yang dirasakan subjek pada skala likert 5 poin.

Sebelum digunakan untuk penelitian, kuesioner kenyamanan kerja dikenai uji coba terlebih dahulu. Uji coba tersebut meliputi uji validitas dan uji reliabilitas. Uji validitas aitem kuesioner dalam penelitian ini dengan mengkorelasikan skor tiap-tiap aitem dengan skor totalnya (criterian of internal consistency), koefisien korelasi berada pada angka 0,30 atau lebih ( $x x y>0,30)$. Berdasarkan hasil uji coba kuesioner kenyamanan kerja diperoleh hasil bahwa dari 72 aitem yang telah diujicobakan terdapat 39 aitem dinyatakan sahih dan 33 aitem lainnya dinyatakan gugur. Rentang koefisien korelasi aitem skala berkisar antara 0,343 sampai dengan 0,843 .

Sedangkan reliabilitas alat ukur dalam penelitian ini menggunakan pendekatan konsistensi internal, yaitu dengan menghitung koefisien reliabilitas Alpha Cronbach. Reliabilitas dinyatakan dengankoefisien reliabilitas (rxx1) yang nilainya berada dalam rentang 0 sampai dengan 1,00. Hasil uji reliabilitas terhadap 39 aitem yang dinyatakan sahih pada kuesioner kenyamanan kerja diperoleh koefisien reliabilitas Alpha sebesar 0,956. Dengan demikian kuesioner kenyamanan kerja yang digunakan dalam eksperimen ini memenuhi persyaratan reliabilitas.

Pretest dilaksanakan di PT. Bank Central Asia Divisi Keuangan, Menara BCA 
lantai 20 dan 31 Jalan M.H Thamrin Kav.1 Jakarta Pusat. Kegiatan ini meliputi penyebaran kuesioner kenyamanan kerja kepada kelompok eksperimen (KE) yaitu 15 orang di lantai 31. Selain itu pada hari yang sama pretest juga dilaksanakan pada kelompok kontrol (KK) yaitu 15 orang di lantai 20. Sedangkan perlakuan terhadap kelompok eksperimen dilaksanakan pada saat sebelum pemberian posttest.

\section{Pembahasan}

Data obesevasi menunjukkan bahwa karakteristik pekerjaan yang dilakukan oleh subjek penelitian yaitu mempersiapkan laporan keuangan untuk pihak internal dan eksternal BCA, menganalisis laporan keuangan untuk manajemen $\mathrm{BCA}$, membuat laporan e-SPT elektronik pajak, dan menganalisis pajak sesuai dengan perundang-undangan yang berlaku. Pekerjaan yang dilakukan karyawan tersebut termasuk pekerjaan yang monoton, kurang bervariasi, dan melelahkan. Karena dituntut bekerja satu macam tugas secara profesional dan ketelitian. Kondisi pekerjaan yang demikian berpotensi dapat menyebabkan ketidaknyamanan kerja bagi karyawan dan pada akhirnya dapat menurunkan produktivitas dan dapat menyebabkan kesalahan kerja.

Sedangkan untuk kondisi lingkungan dan ruangan kantor, karyawan bekerja dalam satu ruangan yang dibatasi dengan partisi-partisi setinggi kurang lebih 1 meter untuk dua orang karyawan yang duduk saling membelakangi. Dengan kondisi ruangan yang sejuk, dan tenang. Serta pencahayaan ruangan yang cukup karena dinding sebagian terbuat dari kaca, sedangkan untuk warna dinding berwarna putih. Maka dari pengamatan tersebut diasumsikan bahwa karyawan nyaman berada di lingkungan kantor. Selain itu, musik latar yang didengarkan oleh kelompok eksperimen adalah jenis musik pop Indonesia dan barat yang sesuai dengan selera subjek. Subjek mendengarkan musik menggunakan pemutar musik seperti; handphone, komputer, radio, ipod, dan mp3 player.

Dari hasil skor total kuesioner yang dihitung berdasarkan kategorisasi jenjang (Ordinal). Tujuan kategorisasi ini adalah menempatkan individu ke dalam kelompokkelompok yang posisinya berjenjang menurut suatu kontinum berdasarkan atribut yang diukur (Azwar, 1999). Skor minimal hipotetik skala kenyamanan kerja diperoleh dari 1 x jumlah aitem skala. Jadi, skor minimal hipotetiknya adalah 1 × $39=39$. Skor maksimal hipotetik skala diperoleh dari 5 x jumlah aitem skala. Jadi, skor maksimal hipotetiknya 5 × $39=195$. Sehingga luas jarak sebarannya adalah 195-39 $=156$. Dengan demikian setiap satuan deviasi standarnya bernilai $\sigma=156 / 6=26$, dan mean teoritiknya adalah $\mu=39 \times 3=117$.

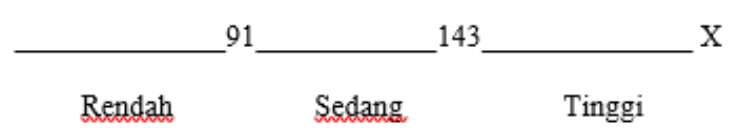

Gambar. 1. Kategorisasi Skor

Berdasarkan hasil pengkategorisasian norma yang telah dibuat, diketahui bahwa tidak terjadi perubahan tingkat kenyamanan kerja yang cukup signifikan pada kelompok kontrol (KK). Hasil pada skor pretest menunjukkan bahwa, 6 orang subjek berada dalam kategori sedang, dan 9 subjek berada dalam kategori tinggi. Dari hasil skor posttest menunjukkan 3 orang subjek masih berada dalam kategori sedang, sedangkan 12 orang subjek berada dalam kategori tinggi. Perbandingan skor pretest dan posttest kelompok kontrol sebagai berikut: 


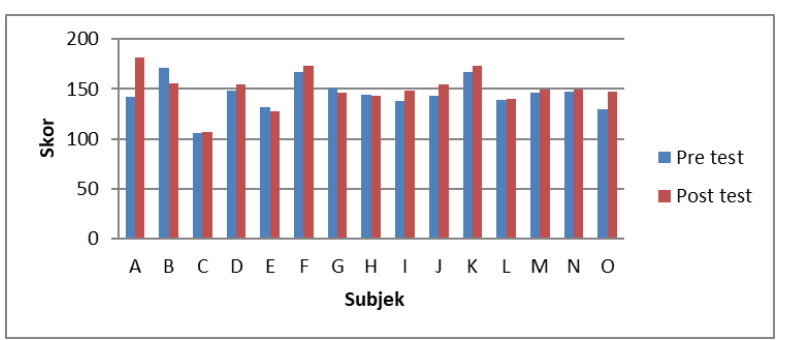

Gambar. 2. Perbandingan Skor Pretest Posttest (KK)

Sedangkan untuk kelompok eksperimen, diketahui bahwa terjadi perubahan tingkat kenyamanan kerja yang signifikan. Hasil skor pretest menunjukkan bahwa kelompok eksperimen, 6 subjek berada dalam kategori sedang, 1 subjek berada dalam kategori rendah, dan 9 subjek berada dalam kategori tinggi. Dari hasil skor posttest menunjukkan 1 orang subjek masih berada pada kategori sedang tetapi tetap mengalami peningkatan skor, sedangkan 14 orang subjek berada pada kategori tinggi. Perbandingan skor pretest dan posttest kelompok eksperimen sebagai berikut:

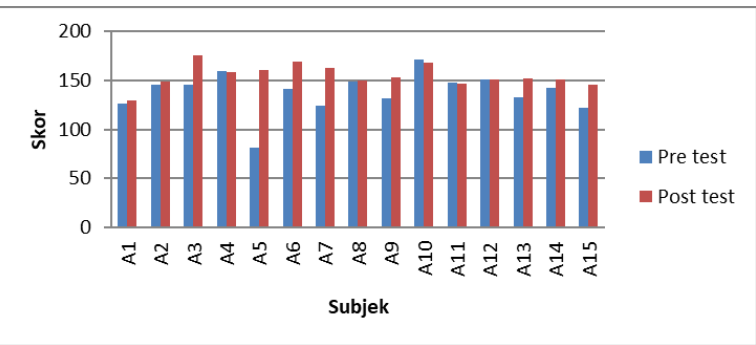

Gambar. 3. Perbandingan Skor Pretest Posttest (KE)

Dari hasil data di atas menunjukkan adanya hubungan positif dan signifikan antara kenyamanan kerja dengan musik latar, dan berdasarkan hasil uji hipotesis dengan menggunakan uji t nilai pretest dan posttest kelompok kontrol menunjukkan nilai $t$ kelompok kontrol sebesar 0,113 ( $\mathrm{p}>$ $0,05)$, artinya tidak ada peningkatan kenyamanan kerja yang signifikan pada kelompok kontrol. Sedangkan pada kelompok eksperimen nilai $t$ sebesar sebesar $0,01 \quad(\mathrm{p}<0,05)$, artinya ada peningkatan kenyamanan kerja yang signifikan pada kelompok eksperimen setelah diperdengarkan musik latar. Maka hipotesis penelitian yang menyatakan bahwa ada peningkatan kenyamanan kerja pada karyawan BCA saat diperdengarkan musik latar diterima.

Dengan demikian hasil penelitian ini mendukung secara empiris penelitian yang dilakukan oleh (Hallam, 2010; Haake, 2006; Lesiuk 2005; Oldham dkk, 1995) yang menyatakan bahwa musik memiliki potensi untuk memberikan dampak positif pada kenyamanan seseorang. Secara umum musik memengaruhi gairah fisiologis, yaitu musik menyenangkan pendengarnya sehingga suasana hati dan emosi menjadi lebih positif, menenangkan dan sebaliknya. Musik latar terbukti mampu membantu karyawan dalam bekerja, karena suasana hati dan emosi karyawan menjadi lebih positif dan akibatnya karyawan cenderung dapat bekerja lebih baik.

Dari hasil penelitian ini juga mengindikasikan bahwa hubungan musik dengan kenyamanan kerja dimulai dari efek musik terhadap suasana hati dan emosi karyawan sehingga musik dapat meningkatkan kenyamanan, semangat, membuat rileks, dan bahagia. Menurut Peretz (dalam Hallam, 2010) musik memiliki efek yang sangat kuat pada suasana hati dan emosi seseorang. Respons ini, seperti yang berkaitan dengan gairah, didasarkan pada hubungannya dengan unsur-unsur musik, misalnya kenyaringan, timbre, pitch dan tempo.

Perlakuan yang diberikan pada kelompok eksperimen dalam penelitian ini adalah memperdengarkan musik latar kepada karyawan yang sebelumnya selama bekerja tidak mendengarkan musik. Sedangkan untuk kelompok kontrol merupakan karyawan yang biasa mendengarkan musik saat bekerja. Hal ini dilakukan untuk melihat pengaruh dari perlakuan musik latar terhadap kelompok eksperimen. Selama perlakuan subjek mendengarkan musik saat setelah makan siang atau setelah jam istirahat yaitu pada 
pukul 13.00 - 15.00. Pemberian perlakuan pada waktu tersebut diasumsikan bahwa ketahanan tubuh dan kenyamanan kerja karyawan sudah mulai menurun. Hal tersebut diperkuat oleh pendapat Tarwaka, dkk (2004) bahwa kelelahan subjektif biasanya terjadi pada akhir jam kerja.

Subjek mendengarkan musik latar menggunakan pemutar musik seperti radio, ipod, komputer, hand phone, dan mp3 player dengan menggunakan earphone. Menurut Haake (2006) ada keuntungan dan kerugian yang ditimbulkan ketika mendengarkan musik dengan menggunakan earphone, keuntungannya bahwa karyawan dapat menghindar dari gangguan rekan kerja mereka sehingga dapat lebih berkonsentrasi dalam bekerja. Sedangkan kerugiannya adalah karyawan tidak dapat berinteraksi dengan rekan kerja dan seolah menarik diri dari rekan-rekan kerjanya.

Dari preferensi musik yang didengarkan oleh kelompok eksperimen didapatkan rata-rata subjek mendengarkan musik pop barat dan Indonesia. Hal ini menunjukkan bahwa jenis musik pop merupakan jenis musik yang familiar bagi orang Indonesia pada umumnya. Preferensi musik subjek diketahui dengan meminta subjek untuk menuliskan musik yang mereka dengar dengan jawaban bebas pada lembar kuesioner kenyamanan kerja. Pemilihan musik secara bebas ini dimaksudkan untuk meminimalkan efek yang mengganggu saat karyawan mendengarkan musik.

Karena para peneliti menyimpulkan bahwa preferensi, keakraban atau pengalaman masa lalu dengan musik yang didengar memiliki pengaruh pada perubahan perilaku positif dibandingkan dengan jenis musik yang tidak disukai/familiar (Lesiuk, 2005). Selain itu, Oldham, dkk (1995) menjelaskan bahwa karyawan dengan pekerjaan yang lebih kompleks atau yang membutuhkan konsentrasi yang lebih ketika mendengarkan musik yang tidak familiar dapat menyebabkan penurunan kinerja.

Pengaruh musik latar dalam kaitannya dengan aktivitas kerja berfungsi untuk mempertahankan semangat kerja, meningkatkan kenyamanan, mengurangi kebosanan, kelelahan, meningkatkan produktivitas, serta mengurangi kesalahan kerja. Subjek yang mendengarkan musik latar saat bekerja telah ada peningkatan yang signifikan dalam kenyamanan, dan secara keseluruhan mengurangi kebosanan kerja. Hasil penelitian ini menunjukkan bahwa musik latar dapat memberikan manfaat dan memiliki pengaruh pada peningkatan kenyamanan kerja karyawan.

Hasil penelitian ini menunjukkan ada perbedaan kenyamanan kerja antara karyawan yang mendengarkan musik latar dengan karyawan yang tidak mendengarkan musik latar. Penelitian ini merupakan langkah awal menuju pemahaman bagaimana kenyamanan kerja dapat dipertahankan dan ditingkatkan melalui penggunaan musik latar yang sesuai dengan selera karyawan. Karena musik yang sesuai dengan selera karyawan merupakan elemen penting dalam meningkatkan kenyamanan karyawan dalam bekerja. Walaupun ada perbedaan antara mereka yang bekerja pada pekerjaan yang sederhana atau pekerjaan yang kompleks/sulit. Hal ini penting untuk melakukan penelitian lebih lanjut terhadap fenomena ini karena ada kemungkinan bahwa fungsi musik mungkin bervariasi, tergantung pada konteks pekerjaannya.

Meskipun data dalam penelitian ini tidak mengungkapkan secara spesifik tentang musik tertentu yang didengarkan oleh karyawan, tetapi jelas bahwa karyawan dengan tingkat kenyamanan yang rendah dan sedang merasa lebih diuntungkan ketika mendengarkan musik. Hasil ini juga mengindikasikan bahwa musik dipercaya dapat menciptakan kinerja lebih baik dan 
peningkatan kemampuan untuk menghadapi situasi stres. Meskipun penelitian empiris lebih lanjut diperlukan untuk mengklarifikasi pernyataan ini.

\section{Penutup}

Hasil penelitian ini menunjukkan ada perbedaan kenyamanan kerja antara karyawan yang mendengarkan musik latar dengan karyawan yang tidak mendengarkan musik latar. Penelitian ini merupakan langkah awal menuju pemahaman bagaimana kenyamanan kerja dapat dipertahankan dan ditingkatkan melalui penggunaan musik latar yang sesuai dengan selera karyawan. Karena musik yang sesuai dengan selera karyawan merupakan elemen penting dalam meningkatkan kenyamanan karyawan dalam bekerja. Walaupun ada perbedaan antara mereka yang bekerja pada pekerjaan yang sederhana atau pekerjaan yang kompleks/sulit. Hal ini penting untuk melakukan penelitian lebih lanjut terhadap fenomena ini karena ada kemungkinan bahwa fungsi musik mungkin bervariasi, tergantung pada konteks pekerjaannya.

Meskipun data dalam penelitian ini tidak mengungkapkan secara spesifik tentang musik tertentu yang didengarkan oleh karyawan, tetapi jelas bahwa karyawan dengan tingkat kenyamanan yang rendah dan sedang merasa lebih diuntungkan ketika mendengarkan musik. Hasil ini juga mengindikasikan bahwa musik dipercaya dapat menciptakan kinerja lebih baik dan peningkatan kemampuan untuk menghadapi situasi stres. Meskipun penelitian empiris lebih lanjut diperlukan untuk mengklarifikasi pernyataan ini.

\section{Referensi}

Azwar, S. 1999. Penyusunan Skala Psikologi. Pustaka Pelajar Offset, Yogyakarta.
.2011. Reliabilitas dan Validitas. Edisi ke tiga, Pustaka Pelajar Offset,

Yogyakarta.

Crozier, W. Ray. 2003. Music and Social Influence. In Hargreaves, David J.\&

North, Adrian C., The Social Psychology of Music. Oxford University

Press.

Compton, W.C. 2005. Introduction to Positive Psychology. New York: Thomson

Wodsworth.

Diener, E. dkk. 1999. Subjective Well Being : Three Decades of Progress.

Psychological Bulletin, 2: 276-302.

Djohan. 2005. Psikologi Musik. Penerbit Buku Baik. Yogyakarta.

.2009. Respons Emosi Musikal. Joglo

Alit. Yogyakarta.

Goleman, Daniel. 2002. Primal Leadership: Realizing the Power of

Emotional Intelligence. Harvard Business School Press.

Garlin, Francine V \& Owen, Katherine. 2006. Setting the tone with the

tune: A meta-analytic review of the effects of background music in

retail settings". Journal of Business Research No.59: p. 755-764.

Gosling, Samuel D \& Rentfrow, Peter J. 2003.

“The Do Re Mi's of

Everyday Life: The Structure and Personality Correlates of Music Preferences". Journal of Personality and Social Psychology. Vol. 84, No. 6: p. 12361256,

Griffin, Michael. 2006. “Background Music and The Learning Environment:

Borrowing From Other Disciplines". Research Project Submitted for The

Degree of Master. Educational Studies School of Education. University Of

Adelaide.

Haake, Anneli B. 2006. "Music listening practices in workplace settings in the

UK: an exploratory survey of office-based settings". Journal Department of Music University of Sheffield, U.K. 
Hallam, Susan. 2010. The effects of background music on health and well Being.

Institute of Education, University of London. Idrus, M. 2006. “Implikasi Iklim Organisasi Terhadap Kepuasan Kerja dan

Kualitas Kehidupan Kerja Karyawan". Jurnal Psikologi. Vol III, No. 1.

Universitas Diponegoro. Semarang.

Jewell, L.N. \& Siegall, Marc. 1998. Psikologi Industri/Organisasi Modern:

Psikologi Terapan untuk Memecahkan Berbagai Masalah di Tempat

Kerja, Perusahaan, Industri, dan Organisasi. Edisi Kedua. Editor Danuyasa A. Jakarta. Arcan.

Keyes, C.L.M., Shmotkin, D., \& Ryff, C.D. 2002. "Optimizing well-being: The

empirical encounter of two traditions". Journal of Personality and Social

Psychology, 82, 1007-1022.

Kusumaningrum, N.S. \& Soetedja. 2003. "Hubungan Kelelahan Kerja dengan

Kecenderungan Mengalami Kecelakaan Kerja". Jurnal Ilmiah Psikologi.

Vol.1 No. 1. 3-8. Insight.

Krumhansl, Carol L. 2002. "Music: A Link Between Cognition and Emotion".

Department of Psychology, Cornell University. Ithaca, New York.

Laukka, P. 2007. “Use Of Music and Psychological Well-Being Among The

Elderly". Journal of Happiness Studies, $8: 215-241$.

Lesiuk, T. 2005. "The Effect of Music Listening On Work Performance".

Psychology of Music, 33(2): p. 173-191.

MacDonald, R., Hargreaves, D.J. \& Miell, D. 2009. Musical identities. In S.

Hallam, I. Cross \& M. Thayer (eds). Oxford Handbook of Music

Psychology. (Oxford: Oxford University Press). p. 462-470.

McAuley J. Devin. 2010. Music Perception. Springer Handbook of Auditory
Research, New York.

Oldham, G., Cummings, A., Mischel, L., Schmidtke, J. \& Zhou, J. 1995. "Listen

while you work? Quasi-experimental relations between personal stereo

headset use and employee work responses". Journal of Applied Psychology. 80 (5): 547-564.

Poels. K., Dewitte. S. 2000. How to Capture The Heart? Reviewing 20 Years of

Emotions in Advertising. Dept. of Communication Sciences, Ghent

University. Belgium.

Robazza, C. Macaluso, C., \& D’Urso, V. 1994. "Emotional Reactions to music by

gender, age and expertise". Perceptual and Motor Skills. 79: 939-944.

Robbins, Stephen, 1996, Organizational Behavior. Prentice Hall. New Jersey. Russell, J.E.A. 2008. Promoting Subjective Well-Being at Work. Journal of

Career Assessment, 16: 118-132.

Ryff, C.D., B.H. Singer and G.D. Love. 2004. "Positive health: Connecting well

being with biology". Philosophical Transactions of the Royal Society of

London Series B. Biological Sciences, 359: 1383-1394.

Schimmack, U. (2006). The structure of subjective wellbeing. University of

Toronto, Mississauga. Department of Psychology, Kanada.

Shek, Vivian., \& Schubert, Emery. 2009.

"Background Music at Work - A

literature review and some hypotheses". The Second International

Conference on Music Communication

Science. The University of New

South Wales. Sydney.

Tarwaka; Bakri, S.H.A; dan Sudiajeng, L. 2004. Ergonomic untuk Kesehatan,

Kesehatan Kerja dan Produktivitas. Surakarta: UNIBA Press. 
76 ] M. Alfiah Akbar: Pengaruh Musik Latar Terhadap Kenyamanan Kerja

Watson, David., Clark L. Anna.1988.

"Development and Validation of Brief

Measures of Positive and Negative Affect: The PANAS Scales".

University of Minnesota. Journal of Personality and Social Psychology. Vol. 54. No. 6, 1063-1070. 